\title{
Health behaviors and quality of life in fertile women using contraception
}

\author{
Zachowania prozdrowotne a jakość życia kobiet w wieku rozrodczym \\ stosujących antykoncepcję
}

\author{
Joanna Błażejewska¹, Dorota Branecka-Woźniak ${ }^{1 凶}$, Marta Stanisz¹, Przemysław Ciepiela¹, Anna Jurczak², \\ Jolanta Wesołowska³, Rafał Kurzawa'
}

${ }^{1}$ Pomorski Uniwersytet Medyczny w Szczecinie, Katedra i Zakład Ginekologii i Zdrowia Prokreacyjnego, ul. Żołnierska 48, 71-210 Szczecin

Pomeranian Medical University, Chair and Department of Gynecology and Reproductive Health

${ }^{2}$ Pomorski Uniwersytet Medyczny w Szczecinie, Zakład Pielęgniarstwa Specjalistycznego, ul. Żołnierska 48, 71-210 Szczecin

Pomeranian Medical University, Department of Clinical Nursing

${ }^{3}$ Pomorski Uniwersytet Medyczny w Szczecinie, Zakład Dermatologii Estetycznej, al. Powstańców Wlkp. 72, 70-111 Szczecin

Pomeranian Medical University, Department of Esthetic Dermatology

$\triangle$ dobrawo@gmail.com

\begin{abstract}
Introduction: Early sexual initiation, the phenomenon of promiscuity, and voluntary childlessness are some reasons behind contraception use by women. Health-related behaviors determine the state of human health and are closely related to quality of life. The aim of the study was to analyze the manifestations of prohealth behaviors and to examine their impact on the quality of life in a group of fertile women using any form of contraception. Materials and methods: Research material was collected from August 2017 to January 2018 in the West Pomeranian Voivodship, from 183 women of childbearing age who had been using contraception. The questionnaire consisted of a author's part and the WHOQOL-BREF questionnaire. Statistical analysis used descriptive and analytical methods, such as the Shapiro-Wilk test and the analysis of variance (ANOVA) test. A structure index containing a percentage was used. The results obtained were statistically analyzed using $\chi^{2}$ test for independent samples. The probability value of $\mathrm{p}<0.05$ was considered statistically significant.

Results: Among pro-health behaviors, $80.9 \%$ of the women declared that they performed some physical activity at least once
\end{abstract}

a week, $76 \%$ stated that their eating habits were correct, $47 \%$ went to a gynecologist once a year, $83.6 \%$ claimed they regularly performed preventive examinations. The better the subjective assessment of health, the higher the quality of life in the psychological domain $(p<0.001)$. The better the nutritional habits were assessed, the better the quality of life in the environment domain $(\mathrm{p}<0.05)$. Not using stimulants had a positive impact on the quality of life in the physical health domain $(p<0.05)$. A rise in the frequency of follow-up visits to a gynecologist led to a rise in the quality of life in social relationships and physical health domains $(\mathrm{p}<0.05)$.

Conclusions: The manifestation of pro-health behaviors in women of childbearing age who use contraception has a positive influence on the quality of their lives in almost all the domains. The overriding purpose of pro-health education is to strengthen the actions of women who display healthy behaviors and, in the case of those exposed to a reduced quality of life due to unhealthy practices, conduct intervention and preventive actions while respecting the woman's individual biopsychosocial needs.

Keywords: health promotion; quality of life; contraception; counseling.

\begin{abstract}
ABSTRAKT
Wstęp: Wczesna inicjacja seksualna, zjawisko promiskuityzmu oraz dobrowolna bezdzietność są przyczynami stosowania antykoncepcji przez kobiety. Zachowania prozdrowotne determinują stan zdrowia człowieka i pozostają w ścisłym związku z jakością życia.

Celem badań była analiza przejawianych zachowań prozdrowotnych oraz ich wpływu na jakość życia w grupie kobiet $w$ wieku rozrodczym stosujących dowolną antykoncepcję.

Materiały i metody: Materiał badawczy zbierano w okresie od sierpnia 2017 do stycznia 2018 r. w województwie zachodniopomorskim wśród 183 kobiet w wieku rozrodczym stosujących antykoncepcję. Ankieta składała się z części autorskiej oraz kwestionariusza WHOQOL-BREF. W analizie statystycznej posłużono się metodami opisowymi i analitycznymi, takimi jak test Shapiro-Wilka oraz wariancja ANOVA (analysis of variance).
\end{abstract}

Użyto wskaźnika struktury zawierającego udział procentowy. Uzyskane wyniki badań poddano analizie statystycznej testem $\chi^{2}$ dla prób niezależnych. Wartość prawdopodobieństwa $\mathrm{p}<0,05$ uznano za statystycznie istotną.

Wyniki: Wśród deklarowanych zachowań prozdrowotnych $80,9 \%$ kobiet wskazało podejmowanie co najmniej raz w tygodniu aktywności fizycznej, 76\% uznało swoje nawyki żywieniowe za prawidłowe, $47 \%$ raz w roku udawało się na wizytę kontrolną do lekarza ginekologa, a 83,6\% regularnie wykonywało badania profilaktyczne. Im lepsza była subiektywna ocena stanu zdrowia, tym wyższa była jakość życia w dziedzinie psychologicznej ( $\mathrm{p}<0,001)$. Im lepiej oceniane były nawyki żywieniowe, tym lepsza była jakość życia w dziedzinie środowiskowej $(p<0,05)$, natomiast niestosowanie używek wpływało na lepszą jakość życia w dziedzinie fizycznej $(\mathrm{p}<0,05)$. Zwiększona częstotliwość 
wizyt kontrolnych u lekarza ginekologa powodowała wzrost jakości życia w dziedzinie społecznej i fizycznej $(\mathrm{p}<0,05)$. Wnioski: Przejawianie zachowań prozdrowotnych przez kobiety w wieku rozrodczym stosujące antykoncepcję wpływa pozytywnie na jakość ich życia niemal we wszystkich dziedzinach Celem nadrzędnym w prowadzeniu edukacji prozdrowotnej jest wzmocnienie działań kobiet przejawiających zachowania sprzyjające zdrowiu, natomiast w przypadku osób narażonych na obniżoną jakość życia z powodu stosowania niekorzystnych dla zdrowia praktyk prowadzenie działań interwencyjnych i profilaktycznych, przy jednoczesnym poszanowaniu indywidualnych potrzeb biopsychospołecznych.

Słowa kluczowe: promocja zdrowia; jakość życia; środki antykoncepcyjne; poradnictwo.

\section{INTRODUCTION}

The reproductive age begins when a female develops the biological capacity to bear a child. This is associated with the appearance of menarche, being an indication of puberty. Childbearing age is a dynamic stage in a woman's life, as well as the longest, beginning around the age of $12-13$, and ending around the age of $50[1,2]$, with the woman having the greatest reproductive capacity between 20-25 years old. Fertility gradually decreases in the subsequent years, declining to a dramatically low level at the age of 37 [3], and ceases with the exhaustion of the ovarian reserve and the occurrence of menopause [4, 5]. Although statistically, women have their $1^{\text {st }}$ sexual intercourse between the ages of 18 and 19, the age of sexual initiation among teenagers is constantly earlier. This generates a number of risks related to procreational health, from the commonly observed phenomenon of promiscuity, to sexually-transferred diseases, to unwanted pregnancies, and especially in minors $[6,7]$. Contraception, understood as the methods and means of limiting natural childbearing potential and helping avoid unintended pregnancy, is a tool for informed birth planning.

The choice of the individual birth control method should be determined by the will to temporarily limit fertility, the accuracy of the method, the woman's health, as well as socioeconomic, cultural and religion-related aspects. Among the contraceptives most frequently used by women are hormonal (oral contraceptives) and mechanical (male condom) birth control methods $[7,8,9]$. Both are widely availability, and the possibility of using them effectively and inexpensively are the most important factors in managing reproduction, which can occur voluntarily and according to one's own preferences [10]. Using certain forms of contraception, e.g., hormonal methods, is associated with the risk of long term side effects, such as venous thromboembolic disease, carbohydrate and lipid metabolic disorders, depression, and a drop in libido, which may have a negative effect on health.

A declining trend in the number of children born in developed countries has been observed. The total fertility rate is decreasing and the average age for women who become pregnant for the first time is simultaneously rising [11]. The average age of primiparas in Poland is 27, which means it occurs at a time when the drop in fertility begins [12]. There is also a new phenomenon called voluntary childlessness, which is referred to as "a childfree lifestyle" $[13,14]$. The postponement of motherhood by women is predominantly justified by such factors as; the will to ensure financial security; the will and opportunities to pursue education; ambitions and professional goals; instability of contemporary relationships; and culturerelated circumstances, which include conflicts between social, professional, and family roles [15]. Women who use contraception constitute a large group of patients under gynecological care. The quality of life (QOL) of these women is becoming a crucial aspect in modern healthcare whose foundations are based on a holistic view of the patient.

Quality of life is an interdisciplinary term, analyzed at the population level, and common in many fields of science, including medicine and health sciences [16]. The World Health Organization (WHO) has distinguished 4 interrelated domains of QOL: physical health, psychological, social relationships, and environment. Health behaviors determine an individual's health condition, the foundation of their proper functioning in the physical and psychological areas, which also allows them to do everyday tasks, modify the environment around them, and perform social roles. What can be observed, then, is a clear causal link between health behaviors and the QOL domains.

Actions undertaken by medical personnel include carrying out proper and effective educational activities as well as promoting health behaviors among patients. Using the results of the study presented in this paper will allow health professionals to establish priorities in the context of health education and health promotion. Becoming acquainted with and including the measurable impact of a subjective assessment of health condition and specific health behaviors on the patient's QOL will be a sign of a holistic perception of this patient, an approach which meets the criteria of high-quality healthcare. The aim of the study therefore was to analyze demonstrated health behaviors and examine their influence on the QOL in a group of women of fertile age who use any method of contraception.

\section{MATERIALS AND METHODS}

The study was conducted between August 2017 and January 2018 in the West Pomeranian Voivodship of Poland. It comprised 183 women of reproductive age. The eligibility criterion for the study was using any form of contraception (mechanical, hormonal, chemical, natural, etc.). The participation in the study was voluntary and anonymous. The study was based on a diagnostic survey method using an independent questionnaire and a standardized WHOQOL-BREF questionnaire. The proprietary survey questionnaire consisted of the following parts: the respondent's particulars, in order to collect 
socio-demographic data and information about the form of contraception used; and questions about the respondent's health behaviors (physical activity, nutritional habits, drugs/ stimulants used, and medical checkups). The WHOQOL-BREF questionnaire, designed by the WHO, measures QOL based on 4 domains: physical health, psychology, social relationships, and the environment. Each domain is broken down into subdomains (facets). The questionnaire consists of 26 single-choice questions, and responses are assessed on a five-point scale. Domain scores are scaled in a positive direction (i.e., the higher the score, the higher the QOL). An exception to this are 3 subdomains scaled in a negative direction: pain and discomfort; dependence on medicinal substances, and medical aids; and the subdomain of negative feelings. Statistical computations, data processing and editing of the compiled materials were carried out using Microsoft Word 2016, Microsoft Excel 2016 and SPSS Statistics 21.0 software. The variables were presented with descriptive statistics incorporating the following measures: the number of valid cases; arithmetic mean; standard deviation; median; and the sample maximum and minimum values. The statistical analysis was based on descriptive and analytical methods such as: Shapiro-Wilk test and analysis of variance (ANOVA). The indicator of structure was interpreted as a percentage. The data obtained were subjected to $\chi^{2}$ test for statistical independence. A significance level of $5 \%$ was adopted. The probability $\mathrm{p}<0.05$ was considered statistically significant.

\section{RESULTS}

The mean age of the women surveyed was 31.59 years. The youngest respondent was 18 years old, and the oldest 54 years. The largest age group - $58(31.7 \%)$ - was between the ages of 18-23 years. The majority of the 183 respondents lived in cities with more than 100,000 residents -58 women $(31.7 \%)$. More than half of the women surveyed - 99 (54.1\%) - had a higher-education degree. The majority of the respondents $146(79.8 \%)$ - were active professionally, while 37 (20.2\%) were not. A little less than half of the women were married - 91 (49.7\%). More than half of the women subjectively assessed their health condition as good - $114(62.3 \%)$. The vast majority of the respondents - $148(80.9 \%)$ - claimed to have been performing physical activity at least once a week. More than three-quarters of the respondents expressed their eating and nutritional habits as proper -139 (76\%). More than half of the women surveyed - 112 (61.2\%) - had been using drugs/stimulants (Tab. 1).

The majority of respondents in the group of 112 women who claimed to have been using drugs/stimulants selected coffee 98 (87.5\%), and cigarettes - 57 (50.9\%) - Table 2.

In the question about the method of contraception currently used, 91 women (49.7\%) selected mechanical contraceptives. Little less frequently used was the hormonal method -73 women $(40.4 \%)$ - Table 3 .

The majority of respondents said they went for gynecological check-ups once a year - 86 women (47.0\%), while 41 women (22.4\%) went twice a year (Tab. 4).
TABLE 1. Data about the women participating in the study $(n=183)$

\begin{tabular}{|c|c|c|c|}
\hline & Data type & Number & $\%$ \\
\hline \multirow[t]{5}{*}{ Age } & $18-23$ & 58 & 31.7 \\
\hline & $24-29$ & 34 & 18.6 \\
\hline & $30-35$ & 21 & 11.5 \\
\hline & $36-40$ & 22 & 12.0 \\
\hline & $>41$ & 48 & 26.2 \\
\hline \multirow{4}{*}{$\begin{array}{l}\text { Place of } \\
\text { residence }\end{array}$} & village & 44 & 24.0 \\
\hline & city with $<10,000$ residents & 27 & 14.8 \\
\hline & $\begin{array}{l}\text { city with } 10,000-100,000 \\
\text { residents }\end{array}$ & 54 & 29.5 \\
\hline & city with $>100,000$ residents & 58 & 31.7 \\
\hline \multirow[t]{5}{*}{ Education } & primary education & 1 & 0.5 \\
\hline & lower secondary education & 10 & 5.5 \\
\hline & vocational & 18 & 9.8 \\
\hline & upper secondary education & 55 & 30.1 \\
\hline & higher education & 99 & 54.1 \\
\hline \multirow[t]{4}{*}{ Marital status } & single & 39 & 21.3 \\
\hline & married & 91 & 49.7 \\
\hline & divorced/widowed & 7 & 3.8 \\
\hline & domestic partnership & 46 & 25.1 \\
\hline \multirow{2}{*}{$\begin{array}{l}\text { Professional } \\
\text { activity }\end{array}$} & working & 146 & 79.8 \\
\hline & non-working & 37 & 20.2 \\
\hline \multirow{3}{*}{$\begin{array}{l}\text { Health } \\
\text { condition }\end{array}$} & very good & 53 & 29.0 \\
\hline & good & 114 & 62.3 \\
\hline & medium & 16 & 8.7 \\
\hline \multirow{2}{*}{$\begin{array}{l}\text { Physical } \\
\text { activity }\end{array}$} & yes & 148 & 80.9 \\
\hline & no & 35 & 19.1 \\
\hline \multirow[t]{2}{*}{ Eating habits } & proper & 139 & 76.0 \\
\hline & improper & 44 & 24.0 \\
\hline \multirow{2}{*}{$\begin{array}{l}\text { Drug/stimulant } \\
\text { use }\end{array}$} & yes & 112 & 61.2 \\
\hline & no & 71 & 38.8 \\
\hline
\end{tabular}

TABLE 2. Types of drugs/stimulants used

\begin{tabular}{lcc}
\multicolumn{1}{c}{ Type of drugs/stimulants used } & $\mathbf{n}$ & \% \\
\hline Cigarettes & 57 & 50.9 \\
\hline Alcohol & 5 & 4.5 \\
\hline Coffee & 98 & 87.5 \\
\hline Other & 1 & 0.9 \\
\hline
\end{tabular}

$n$ - number of valid cases

The vast majority of respondents - 153 women (83.6\%) claimed to have routine prophylactic check-ups, in the sense of medical examinations performed in accordance with their specific recommendations, e.g., breast self-examination performed 2-3 days after every menstruation, undergoing cytology testing once a year (Tab. 5).

In the group of 153 women claiming to have regular prophylactic medical check-ups, the majority of respondents selected undergoing cytology - 133 women (86.9\%). More than 
TABLE 3. Types of contraceptives currently used in the study group

\begin{tabular}{|c|c|c|c|c|c|c|}
\hline \multirow{2}{*}{ Type of contraception currently used } & \multicolumn{2}{|c|}{ Yes } & \multicolumn{2}{|c|}{ No } & \multicolumn{2}{|c|}{ Total } \\
\hline & $\mathbf{n}$ & $\%$ & n & $\%$ & n & $\%$ \\
\hline $\begin{array}{l}\text { Mechanical contraception (intrauterine devices and barrier-methods: male and } \\
\text { female condoms, diaphragm) }\end{array}$ & 91 & 49.7 & 92 & 50.3 & 183 & 100.0 \\
\hline $\begin{array}{l}\text { Hormonal contraception (two-ingredient monophasic/biphasic/triphasic } \\
\text { oral pills, progestin-only pills, subcutaneous and intramuscular injections, } \\
\text { hormonal intrauterine devices, contraceptive patches, vaginal rings) }\end{array}$ & 74 & 40.4 & 109 & 59.6 & 183 & 100.0 \\
\hline Chemical contraception (spermicidal gels, creams, foams, suppositories) & 1 & 0.6 & 182 & 99.5 & 183 & 100.0 \\
\hline $\begin{array}{l}\text { Natural contraception (the temperature method, the sympto-thermal method, } \\
\text { the Billings ovulation method, Persona contraception monitor) }\end{array}$ & 26 & 14.2 & 157 & 85.8 & 183 & 100.0 \\
\hline Other (rejected sexual intercourse) & 12 & 6.6 & 171 & 93.4 & 183 & 100.0 \\
\hline
\end{tabular}

$n$ - number of valid cases

TABLE 4. The frequency of gynecological check-ups among the women surveyed

\begin{tabular}{lcc}
$\begin{array}{c}\text { The frequency of gynecological } \\
\text { check-ups }\end{array}$ & $\mathbf{n}$ & $\%$ \\
\hline Twice a year & 41 & 22.4 \\
\hline Once a year & 86 & 47.0 \\
\hline Less than once a year & 48 & 26.2 \\
\hline Do not go to a doctor & 8 & 4.4 \\
\hline Total & 183 & 100.0 \\
\hline
\end{tabular}

$n$ - number of valid cases
TABLE 5. Regularity of prophylactic medical check-ups in women surveyed

\begin{tabular}{lcc}
\multicolumn{1}{c}{$\begin{array}{c}\text { Regularity of prophylactic } \\
\text { check-ups }\end{array}$} & $\mathbf{n}$ & \% \\
\hline Yes & 153 & 83.6 \\
\hline No & 30 & 16.4 \\
\hline Total & 183 & 100.0 \\
\hline
\end{tabular}

$n$ - number of valid cases

TABLE 6. Types of prophylactic check-ups performed

\begin{tabular}{|c|c|c|c|c|c|c|}
\hline \multirow{2}{*}{ Prophylactic check-ups performed } & \multicolumn{2}{|c|}{ Yes } & \multicolumn{2}{|c|}{ No } & \multicolumn{2}{|c|}{ Total } \\
\hline & $\mathrm{n}$ & $\%$ & $\mathbf{n}$ & $\%$ & $\mathrm{n}$ & $\%$ \\
\hline Breast self-examination & 91 & 59.5 & 62 & 40.5 & 153 & 100.0 \\
\hline Cytology & 133 & 86.9 & 20 & 13.1 & 153 & 100.0 \\
\hline Mammography & 28 & 18.3 & 125 & 81.7 & 153 & 100.0 \\
\hline Laboratory blood test & 87 & 56.9 & 66 & 43.1 & 153 & 100.0 \\
\hline Chest X-Ray & 34 & 22.2 & 119 & 77.8 & 153 & 100.0 \\
\hline Ultrasonography of the female reproductive organs & 86 & 56.2 & 64 & 43.8 & 153 & 100.0 \\
\hline Blood pressure measurement & 80 & 52.3 & 73 & 47.7 & 153 & 100.0 \\
\hline Other (breast ultrasound) & 4 & 2.6 & 149 & 97.4 & 153 & 100.0 \\
\hline
\end{tabular}

$n$ - number of valid cases

half of the respondents perform breast self-examination - 91 women (59.5\%), 87 women (56.9\%) have blood tests done, and 86 women (56.2\%) have ultrasonography of the female reproductive organs done (Tab. 6)

The study has shown a significant relationship between the assessment of the QOL and the subjective assessment of health condition in the psychological domain. The better the subjective assessment of one's health condition, the higher the QOL in the subdomain of thinking, learning, memory and concentration $(p<0.05)$, understood in terms of a greater efficiency and effectiveness of these processes. Highly significant relations were found between the QOL and the assessment of health condition within the subdomain of spirituality/religion/ personal beliefs $(\mathrm{p}<0.001)$ - Table 7 .
The statistical analysis has shown a significant relationship between the domain of environment and the assessment of eating and nutritional habits. The better the assessment of eating and nutritional habits made by the respondents, the better the QOL in the subdomain of financial resources, understood as the level at which the respondent's financial resources let them satisfy their needs in terms of a healthy and comfortable life, which translates into QOL ( $\mathrm{p}<0.05)$ - Table 8.

The analysis of the QOL with regard to drugs/stimulants usage has revealed a significant relationship in the physical health domain. The women who do not use any drugs/stimulants make a better assessment of their QOL, and are more satisfied with performing activities of daily living (ability to undertake everyday actions and lead a normal life) $(\mathrm{p}<0.05)$ - Table 9. 
TABLE 7. Quality of life in relation to health condition assessment

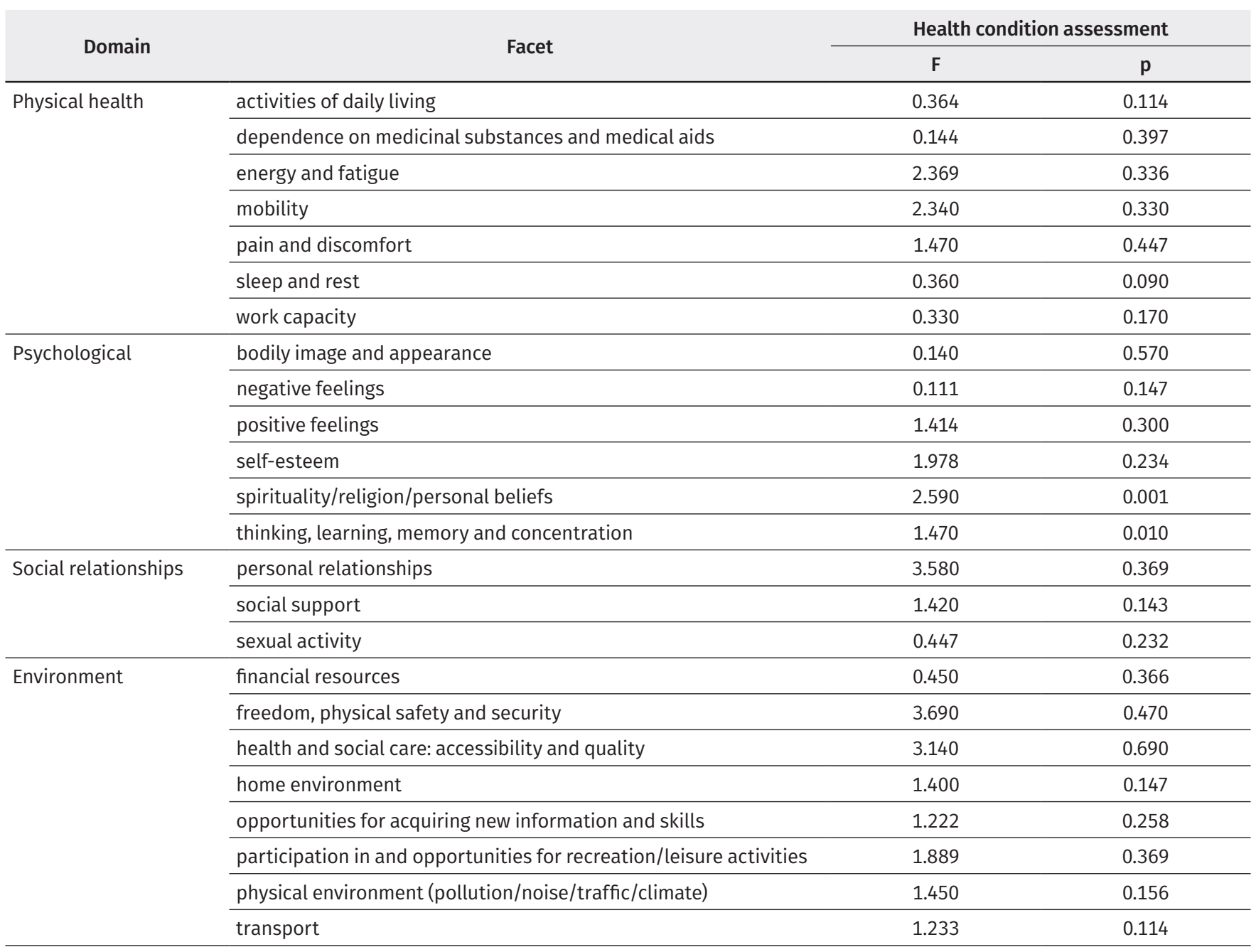

F - ANOVA test results; $\mathrm{p}$ - calculated test probability

TABLE 8. Quality of life in relation to eating and nutritional habits

\begin{tabular}{|c|c|c|c|}
\hline \multirow{2}{*}{ Domain } & \multirow{2}{*}{ Facet } & \multicolumn{2}{|c|}{ Eating and nutritional habits } \\
\hline & & $\mathbf{F}$ & $\mathrm{p}$ \\
\hline \multirow[t]{7}{*}{ Physical health } & activities of daily living & 0.665 & 0.999 \\
\hline & dependence on medicinal substances and medical aids & 0.632 & 0.380 \\
\hline & energy and fatigue & 0.578 & 0.537 \\
\hline & mobility & 0.077 & 0.730 \\
\hline & pain and discomfort & 0.701 & 0.907 \\
\hline & sleep and rest & 0.614 & 0.149 \\
\hline & work capacity & 0.254 & 0.911 \\
\hline \multirow[t]{5}{*}{ Psychological } & bodily image and appearance & 0.158 & 0.706 \\
\hline & negative feelings & 0.853 & 0.938 \\
\hline & self-esteem & 0.237 & 0.822 \\
\hline & spirituality/religion/personal beliefs & 0.869 & 0.154 \\
\hline & thinking, learning, memory and concentration & 0.967 & 0.111 \\
\hline \multirow[t]{3}{*}{ Social relationships } & personal relationships & 0.405 & 0.457 \\
\hline & social support & 0.629 & 0.401 \\
\hline & sexual activity & 0.014 & 0.112 \\
\hline
\end{tabular}




\begin{tabular}{lllr}
\multirow{2}{*}{ Domain } & \multicolumn{1}{c}{ Facet } & \multicolumn{2}{c}{ Eating and nutritional habits } \\
\cline { 3 - 4 } Environment & & $\mathbf{F}$ & $\mathbf{p}$ \\
\cline { 2 - 4 } & financial resources & 1.847 & 0.035 \\
\cline { 2 - 4 } & freedom, physical safety and security & 0.060 & 0.687 \\
\cline { 2 - 4 } & health and social care: accessibility and quality & 0.711 & 0.277 \\
\cline { 2 - 4 } & home environment & 0.572 & 0.805 \\
\cline { 2 - 4 } & opportunities for acquiring new information and skills & 0.161 & 0.646 \\
\cline { 2 - 4 } & participation in and opportunities for recreation/leisure activities & 0.140 & 0.640 \\
\cline { 2 - 4 } & physical environment (pollution/noise/traffic/climate) & 0.761 & 0.209 \\
\cline { 2 - 4 } & transport & 0.625 \\
\hline
\end{tabular}

F - ANOVA test results; $p$ - calculated test probability

TABLE 9. Quality of life in relation to drugs/stimulants use

\begin{tabular}{|c|c|c|c|}
\hline \multirow{2}{*}{ Domain } & \multirow{2}{*}{ Facet } & \multicolumn{2}{|c|}{ Drugs/stimulants use } \\
\hline & & $\mathbf{F}$ & p \\
\hline \multirow[t]{7}{*}{ Physical health } & activities of daily living & 1.555 & 0.021 \\
\hline & dependence on medicinal substances and medical aids & 0.814 & 0.320 \\
\hline & energy and fatigue & 0.506 & 0.972 \\
\hline & mobility & 0.498 & 0.081 \\
\hline & pain and discomfort & 0.679 & 0.153 \\
\hline & sleep and rest & 0.835 & 0.840 \\
\hline & work capacity & 0.137 & 0.190 \\
\hline \multirow[t]{5}{*}{ Psychological } & bodily image and appearance & 0.907 & 0.951 \\
\hline & negative feelings & 0.465 & 0.535 \\
\hline & self-esteem & 0.270 & 0.800 \\
\hline & spirituality/religion/personal beliefs & 0.398 & 0.597 \\
\hline & thinking, learning, memory and concentration & 0.343 & 0.194 \\
\hline \multirow[t]{3}{*}{ Social relationships } & personal relationships & 0.282 & 0.312 \\
\hline & social support & 0.383 & 0.360 \\
\hline & sexual activity & 0.463 & 0.610 \\
\hline \multirow[t]{7}{*}{ Environment } & financial resources & 0.440 & 0.397 \\
\hline & freedom, physical safety and security & 0.945 & 0.100 \\
\hline & health and social care: accessibility and quality & 0.845 & 0.798 \\
\hline & home environment & 0.187 & 0.591 \\
\hline & opportunities for acquiring new information and skills & 0.225 & 0.212 \\
\hline & physical environment (pollution/noise/traffic/climate) & 0.140 & 0.209 \\
\hline & transport & 0.726 & 0.130 \\
\hline
\end{tabular}

F - ANOVA test results; $\mathrm{p}$ - calculated test probability

The statistical analysis has shown a significant relationship between the domains of physical health and social relationships and the frequency of gynecological check-ups. The more often the respondents claimed to have undergone gynecological check-ups, the better their QOL in the subdomains of energy and fatigue (energy resources and the level of fatigue) and sexual activity (libido level, ability to perform and derive pleasure from sexual intercourse) $(\mathrm{p}<0.05)$ - Table 10 .
The statistical analysis of data has not shown a significant statistical relationship between undergoing prophylactic checkups and the QOL in any domain ( $\mathrm{p}>0.05)$ - Table 11.

Individual questions from the WHOQOL-BREF questionnaire produce a general QOL profile, divided into 4 domains: physical health, psychological, social relationships, and environment. Mean score results were obtained within each of the domains. Converting raw scores to transformed scores made it possible 
TABLE 10. Quality of life in relation to the frequency of gynecological check-ups

\begin{tabular}{|c|c|c|c|}
\hline \multirow{2}{*}{ Domain } & \multirow{2}{*}{ Facet } & \multicolumn{2}{|c|}{ Frequency of check-ups } \\
\hline & & $\mathbf{F}$ & p \\
\hline \multirow[t]{7}{*}{ Physical health } & activities of daily living & 0.095 & 0.912 \\
\hline & dependence on medicinal substances and medical aids & 0.023 & 0.126 \\
\hline & energy and fatigue & 1.000 & 0.022 \\
\hline & mobility & 0.677 & 0.933 \\
\hline & pain and discomfort & 0.920 & 0.427 \\
\hline & sleep and rest & 0.924 & 0.811 \\
\hline & work capacity & 0.121 & 0.569 \\
\hline \multirow[t]{5}{*}{ Psychological } & bodily image and appearance & 0.328 & 0.900 \\
\hline & negative feelings & 0.540 & 0.380 \\
\hline & self-esteem & 1.096 & 0.875 \\
\hline & spirituality/religion/personal beliefs & 0.600 & 0.195 \\
\hline & thinking, learning, memory and concentration & 0.406 & 0.240 \\
\hline \multirow[t]{3}{*}{ Social relationships } & personal relationships & 0.547 & 0.416 \\
\hline & social support & 0.451 & 0.783 \\
\hline & sexual activity & 2.210 & 0.050 \\
\hline \multirow[t]{7}{*}{ Environment } & financial resources & 0.280 & 0.640 \\
\hline & freedom, physical safety and security & 0.079 & 0.934 \\
\hline & health and social care: accessibility and quality & 0.310 & 0.557 \\
\hline & home environment & 0.291 & 0.766 \\
\hline & opportunities for acquiring new information and skills & 0.344 & 0.320 \\
\hline & physical environment (pollution/noise/traffic/climate) & 0.204 & 0.209 \\
\hline & transport & 0.837 & 0.175 \\
\hline
\end{tabular}

F-ANOVA test results; $\mathrm{p}$ - calculated test probability

TABLE 11. Quality of life in relation to undergoing prophylactic check-ups

\begin{tabular}{|c|c|c|c|}
\hline \multirow{2}{*}{ Domain } & \multirow{2}{*}{ Facet } & \multicolumn{2}{|c|}{ Having prophylactic check-ups } \\
\hline & & $\mathbf{F}$ & p \\
\hline \multirow[t]{7}{*}{ Physical health } & activities of daily living & 0.308 & 0.355 \\
\hline & dependence on medicinal substances and medical aids & 0.890 & 0.162 \\
\hline & energy and fatigue & 0.811 & 0.568 \\
\hline & mobility & 0.964 & 0.120 \\
\hline & pain and discomfort & 0.100 & 0.599 \\
\hline & sleep and rest & 0.705 & 0.741 \\
\hline & work capacity & 0.229 & 0.763 \\
\hline \multirow[t]{5}{*}{ Psychological } & bodily image and appearance & 0.770 & 0.590 \\
\hline & negative feelings & 1.141 & 0.080 \\
\hline & self-esteem & 0.730 & 0.711 \\
\hline & spirituality/religion/personal beliefs & 0.452 & 0.886 \\
\hline & thinking, learning, memory and concentration & 0.090 & 0.240 \\
\hline \multirow[t]{3}{*}{ Social relationships } & personal relationships & 0.885 & 0.494 \\
\hline & social support & 0.616 & 0.668 \\
\hline & sexual activity & 0.333 & 0.329 \\
\hline
\end{tabular}




\begin{tabular}{llll}
\multirow{2}{*}{ Domain } & \multicolumn{1}{c}{ Facet } & \multicolumn{2}{c}{ Having prophylactic check-ups } \\
\cline { 3 - 4 } Environment & financial resources & $\mathbf{F}$ & $\mathbf{p}$ \\
\cline { 2 - 4 } & freedom, physical safety and security & 0.081 & 0.251 \\
\cline { 2 - 4 } & health and social care: accessibility and quality & 0.159 & 0.080 \\
\cline { 2 - 4 } & home environment & 0.289 & 0.483 \\
\cline { 2 - 4 } & opportunities for acquiring new information and skills & 0.767 & 0.611 \\
\cline { 2 - 4 } & participation in and opportunities for recreation/leisure activities & 0.745 & 0.599 \\
\cline { 2 - 4 } & physical environment (pollution/noise/traffic/climate) & 0.630 & 0.420 \\
\cline { 2 - 4 } & transport & 0.869 & 0.999 \\
\hline
\end{tabular}

F - ANOVA test results; $p$ - calculated test probability

TABLE 12. Quality of life in women of reproductive age using contraception per specific domain, converted to the transformed scores in the range 4-20

\begin{tabular}{lcccc}
\multicolumn{1}{c}{ Domain } & $\mathbf{n}$ & Ms & SD & Mp \\
\hline Physical health & 183 & 28.07 & 3.63 & 16 \\
\hline Psychological & 183 & 23.39 & 3.13 & 15 \\
\hline Social relationships & 183 & 11.96 & 1.85 & 16 \\
\hline Environment & 183 & 30.39 & 3.99 & 15
\end{tabular}

$\mathrm{n}$ - number of valid cases; Ms - mean raw score; SD - standard deviation; Mp mean transformed score

to include them in the range 4-20 points. Higher scores in the WHOQOL-BREF questionnaire denote a higher QOL. The overall QOL in each domain remains at a similar and relatively high level. The score values range between 15-16 (Tab. 12).

The QOL of women in the form of overall score is reflected by a number of points in the range 4-20, resulting from calculating the arithmetic mean of the scores obtained from each domain. The overall score was 15.5 points (Tab. 13).

\section{DISCUSSION}

Women all around the world should have the right to make a free choice about whether they want to have children at all, when they plan to have them, and how many children they wish to have. They can exercise this right with the help of various forms and methods of contraception, which is why one of the most fundamental healthcare services for women is birth control counseling [17]. In modern gynecology it is the woman, perceived in a holistic manner, who is the center of interest for medical personnel. What indicates the effectiveness of healthcare and determines its direction of development is the QOL, which embraces the physical, psychological, social, and environmental aspects. Health behaviors exhibited by patients can either have a positive or negative impact on their health, and therefore they constitute an important aspect of life which, in turn, remains in direct relationship with the QOL. Some of the tasks performed within gynecological care also include health promotion and preventive healthcare, which is why learning about the current lifestyle trends among women of reproductive age who use contraception, as well as analyzing the impact
TABLE 13. Quality of life in women of reproductive age using contraception presented in the form of overall score converted to a transformed score in the range $4-20$

\begin{tabular}{lll}
\multicolumn{1}{c}{ Domain } & Mp & A \\
\hline Physical health & 16 & \\
\cline { 1 - 2 } Psychological & 15 & 15.5 \\
\hline Social relationships & 16 & \\
\hline Environment & 15 & \\
\hline
\end{tabular}

$\mathrm{Mp}$ - mean transformed score; A - arithmetic mean obtained from transformed scores per domain

of their behaviors on their QOL, will allow us to address proper educational and health counseling measures to this group, which will grow and have a positive influence on their QOL.

Self-assessment of health condition is made on the basis of how the woman perceives her ability to function in physical, mental, and social terms [18]. In the proprietary survey, more than $50 \%$ of the women collectively assessed their health condition as good, and $29 \%$ of the respondents said it was very good. This shows that the respondents were satisfied with their health condition. Health self-assessment made by the women was supplemented by additional questions related to their health behaviors, which constitute a behavioral component of human attitude toward health. Healthy behaviors, as opposed to unhealthy behaviors, are conducive to maintaining wellbeing and proper functioning of the organism [19]. Therefore, it can be said that they play a twofold role: they are ontogenetic determinants of health and, simultaneously, they are an expression of an individual's attitude toward it.

Scientific publications distinguish 5 forms of purposeful activities, which are also referred to as health behavior classes. These are: avoiding drugs/stimulants use, implementing positive health practices (e.g., taking up physical activity), proper eating habits (following a well-balanced diet, following the 5 meals a day rule), preventive healthcare behaviors (regular medical check-ups, prophylactic examinations, health selfchecks), and careful driving [20]. The proprietary survey contained questions related to the first 4 of the above-mentioned 5 classes.

A high percentage of respondents display health-conducive behaviors. A large proportion (80.9\%) of respondents claim to perform some form of physical activity, and more than 
3 fourths of the women subjectively assess their eating habits as proper. At the same time, more than half of the women admit to using drugs/stimulants. The most frequently used drug/stimulant is coffee (87.5\%), but what is alarming is the fact that the $2^{\text {nd }}$ most frequent choice is cigarettes (50.9\%). It is important to note that part of the study group were women using various forms of hormonal contraception (40.4\%). The latest reports about mixing hormone-based contraceptives with nicotine confirm an increased risk of hemorrhagic stroke in women who smoke cigarettes and use oral contraceptives $[21,22]$. Another study investigating the attitudes of women using hormonal contraceptives towards quitting smoking has revealed that only $10 \%$ of them stopped smoking after starting to use hormone-based contraception, whereas the remaining $90 \%$, by continuing to smoke, increased their risk of venous thromboembolic disease. This may indicate a low awareness of the risk among such women, or an intentional disregard of and non-compliance with medical recommendations, which may be an important hint about how to formulate healthcare goals. Medical personnel should remember that it is their responsibility to encourage smokers to quit their addiction and promote knowledge about the harmfulness of smoking, as well as inform the patients using hormonal contraception about any possible complications and an increased risk of venous thromboembolic disease if they smoke cigarettes.

Prophylactic medical examinations and regular visits to the doctor constitute another health-conducive class of behaviors. Słopiecka, in her studies on the use of gynecological advice by women, emphasizes that many women do not feel such a need at all, which is caused by a positive self-assessment of their health condition. More than half of the women she surveyed went to the doctor's less frequently than once a year, or did not go at all [23]. Our study has revealed that as many as one in four respondents went to a gynecologist less than once a year. These are alarming reports, considering the respondents' reproductive age and the possibility of them using birth control methods that unconditionally require the patient to perform medical check-ups at least once a year, i.e., all the hormonal and intrauterine methods of contraception [24]. Unfortunately, for many women, it is pregnancy which provides a good reason to visit a gynecologist for the very first time. In the study carried out by Słopiecka, the above-mentioned group constituted a total of $69.5 \%$ of all the respondents, whereas only $21 \%$ of the women had their $1^{\text {st }}$ gynecologist appointment in order to seek advice while being healthy. These results suggest that there is a necessity to promote information among women on the range of services rendered by gynecologists, which are not limited to medical services only, but also involve education, prophylaxis, and health promotion, and encourage women to use these services.

A significant number - $83.6 \%$ - of the respondents who took part in our study stated that they underwent regular prophylactic examinations. Cytology tests were the most frequently indicated examinations performed among the respondents $(86.9 \%)$. Mammography was indicated by only $13.3 \%$ of the respondents, which may be connected with the prevalence of younger age groups who do not yet qualify for this kind of examination within the National Breast Cancer Early Detection Program (eligibility criteria are met by women in their 50. and 60.). At the same time, the age analysis indicates that 1 in 4 respondents are 40 years old or more, and should undergo mammography tests as part of their own health prophylaxis practices. The age distribution within the study group may also have an influence on the high percentage of women who claim to undergo regular cytology tests. The National Cervical Cancer Prevention Program is open to women from 25-59 years, and nearly $75 \%$ of the respondents fall into this age bracket. This means that the cervical cancer prevention program is available to a wider age group than mammography screening, hence the above-mentioned differences. What should be pointed out, though, is the fact that participation of women in examinations within the cervical cancer prevention program is very low, despite constant efforts aiming to popularize it. According to a report by Paszkiewicz and Piotrowski, the average participation of women in the program oscillates around 21.01-23.21\% of the qualifiable population [25]. Similar results were obtained by Leźnicka et al., Karowicz-Bilińska, and Kozimala et al. in 2009, 2008 and 2007 [26, 27, 28]. Therefore, it can be presumed that the respondents who took part in our own survey and claimed to undergo cytology tests mostly do so in the form of a paid option during a follow-up medical appointment, or belong to a small group of women who are the beneficiaries of the National Prevention Program.

Breast self-examination is a basic and completely free type of examination which enables the women to perform diagnostics of changes in the breasts. The only tool required for this examination is a knowledge of how it can be performed. Regular self-examination performed on a monthly basis makes it possible to detect worrying changes in the appearance and structure of a mammary gland. Our study has shown that 59.5\% of women who undergo regular preventive medical checkups perform breast self-examination. Dissimilar results were obtained by other authors whose studies revealed that $89 \%$ and $73 \%$ of women respectively performed a regular selfexamination of their breasts [29, 30]. Breast self-examination can be performed by any woman and requires very little time and no financial investment. Therefore, educational activities should be increased while providing gynecological care, which will equip women with the skills and knowledge necessary to perform self-checks, and women should constantly be informed about the diagnostic usefulness of such examinations.

All human life is characterized by a balance between health and disease. Various external and internal factors (including health behaviors) are determinants of this unstable balance, and they can be conducive to maintaining health or to the occurrence of a disease [31]. Health determines a human being's QOL, and simultaneously it is a state which is significantly impacted on by this quality. They are, therefore, 2 variables which affect one another. Our study has revealed the following correlation: the better the subjective self-assessment of the woman's health, the higher the QOL in the psychological domain. Women who have a better self-assessment of their 
health display superior efficiency and effectiveness with regard to concentration, thinking, and learning and memory capabilities $(\mathrm{p}<0.05)$. Similar correlations can be found in the sense of purpose in life expressed in the subdomain of spirituality/ religion/personal beliefs ( $\mathrm{p} \leq 0.001)$. These can be explained in a few ways. One explanation assumes that a worse QOL with regard to thinking, learning, memory and concentration in people who have a worse self-assessment of their health, has to do with the occurrence of a disease which itself may negatively affect these processes (e.g., depression, diseases that lead to dementia, chronic pain conditions). Bad health conditions may also lower the sense of purpose in life since it takes away carefreeness and joy. At the same time, a possible reason for these correlations, on the grounds of health theory being an important resource in dealing with stress [32], can be the inability to concentrate, which results from worrying about health deterioration and fear of total health loss and serious injuries, or even death as a result of them. What is interesting, though, is the lack of relationship between the subjective self-assessment of health condition and the sense of freedom, physical safety and security $(\mathrm{p}>0.05)$. Health deterioration is usually associated with anxiety, loss of self-confidence, and the feeling of insecurity, which should translate into lowering the QOL in this subdomain. It is possible that a worse subjective assessment of health condition among the respondents does not result from accompanying diseases or the threat of serious injury, which in effect does not have a significant influence on one's sense of security and independence.

The statistical analysis has shown a significant relationship between the QOL in the domain of environment and the assessment of eating and nutritional habits. The better the assessment of eating and nutritional habits made by the respondents, the better the QOL in the subdomain of financial resources $(\mathrm{p}<0.05)$. The above subdomain enables us to rate the degree to which the respondent's financial resources allow a woman to satisfy her needs related to a healthy and comfortable life. Thus, it can be concluded that eating and nutritional habits are influenced by the respondent's financial resources. This theory is proven in a number of reports on public and individual health, which reveal that the size of one's earnings and a person's social status are considered 2 of the most important determinants of a healthy lifestyle. These reports describe a relationship in which those people who earn more money tend to be healthier, and vice versa. The authors also underline the high costs of healthy food products which make it possible to create and follow a well-balanced diet $[33,34]$. That is why dietary and nutrition counseling should involve taking into consideration the economic status of the patient, and try to recommend solutions available to anyone such as eating regular meals, avoiding fatty food, drinking water instead of sweetened beverages.

Our study has indicated that the women who do not use any drugs/stimulants have a better self-assessment of their QOL in the domain of physical health. They are more satisfied with performing activities of daily living, i.e., the ability to undertake everyday actions and lead a normal life $(p<0.05)$. Using drugs/stimulants is often interrelated with the phenomenon of addiction. Considering the above relationship from the point of view of tobacco addiction, which is extremely harmful, the observed correlation seems to be obvious. Cigarette smokers experience a craving for smoking, which has to do with the aspect of motivation for searching and using tobacco products, and the necessity to find time to perform these actions. From the mental point of view, smoking a cigarette lowers insecurity and anxiety, and improves the mood of the people addicted. From the physical point of view, the addiction manifests itself through the drug withdrawal syndrome, which, in turn, manifests itself through hyperactivity, hand tremors, and concentration difficulties, all the symptoms accompanying a longer break from smoking [35]. Addicts make ordinary everyday activities dependent on their addiction, and the addiction constantly interferes with their life. Medical personnel should use this knowledge in support of their arguments about the harmful effect of drugs and stimulants on one's health and life.

The statistical analysis of the data collected has shown a significant relationship between the domain of physical health of the QOL and the frequency of gynecological check-ups. The more often the respondents claimed to undergo gynecological check-ups, the better their QOL in the subdomains of energy and fatigue and sexual activity $(\mathrm{p}<0.05)$.

When attempting to analyze interrelations in the facet of sexual activity, it is important to note that one of the fundamental responsibilities of a gynecologist is to provide sexual education to the patient and carry out an analysis of the patient's needs and problems in this matter. Nusbaum et al., while doing research on women's sexual lives, observed that over $98 \%$ of the patients who visited the gynecologist reported 1 or more sexual problems. Among the problems reported by the respondents were, for example: excessive vaginal dryness, problems with achieving orgasm, and painful intercourse. The respondents also expressed a motivation for conversation about this subject with their lead doctor, hoping to get advice from him or her. Based on this information, Nusbaum et al. concluded that sexual counseling and sexual assistance are an important duty of gynecologists when providing healthcare to the patient [36].

The statistical analysis of data collected has not shown a significant statistical relationship between undergoing prophylactic check-ups and the QOL in any of the domains ( $p>0.05)$. No reports on the relationship between the 2 variables were found in research literature. Still, many authors have analyzed the motives for having prophylactic examinations. One of the reasons mentioned was the fear of and anxiety about a disease $[37,38]$. In this aspect, women who undergo prophylactic medical check-ups should have a better QOL in the psychological and environment domains, especially in terms of physical and mental security, and should rarely experience negative feelings. Therefore, it can be concluded that the respondents in the study group display some other premises for having preventive examinations.

Despite a high percentage of healthy behaviors, some examples of alarming behaviors were identified in the study 
group, too. These include drug/stimulant use, rare visits to the gynecologist, and irregularity in having prophylactic examinations. The examples of healthy behaviors had a positive impact on nearly every QOL domain, which is why it is of great importance to promote proper attitudes and a healthy lifestyle in women's healthcare, and tailor the advice provided to them to the individual biopsychosocial situation of the patient, taking into account both her physical and mental needs.

\section{CONCLUSIONS}

1. Healthy behaviors in women of reproductive age who use contraception have a positive impact on their QOL in almost every domain, i.e., physical health, environment, and social relationships.

2. The main purpose of health education is carrying out reinforcement activities aimed at women who display healthconducive behaviors, as well as carrying out intervention and preventive activities tailor-made to the individual biopsychosocial needs of the women who are at risk of a lower QOL resulting from the practice of unhealthy behaviors.

\section{REFERENCES}

1. Kaczmarek M, Szwed A. Age at menopause and reproductive determinants. Anthropol Rev 2001;64:57-72.

2. Mroczek B, Wróblewska I, Jamrocha K, Jurczak A, Kurpas D. Jakość życia kobiet w okresie menopauzy. Fam Med Prim Care Rev 2014;2:136-7.

3. Szafarowska M, Jerzak M. Procesy starzenia się komórki jajowej a niepłodność. Ginekol Pol 2013;84:298-304.

4. Papadimitriou A. The Evolution of the Age at Menarche from Prehistorical to Modern Times. J Pediatr Adolesc Gynecol 2016;29(6):527-30.

5. Lemm MA, Skałba P. Biologia starzenia się jajników. Prz Menopauz 2013; 12(3):231-4.

6. Such-Pyrgiel M. Miłość, seks i małżeństwo w opiniach i życiowych planach osób żyjących w pojedynkę. J Mod Sci 2015;3(26):11-32.

7. Skibiński A. Uwarunkowania postaw prokreacyjnych i matrymonialnych młodzieży akademickiej województwa śląskiego. Stud Ekonom 2017;309:17-27.

8. Roth MY, Page ST, Bremner WJ. Male hormonal contraception: looking back and moving forward. Androl 2016;4(1):4-12.

9. Behboudi-Gandevani S, Ramezani Tehrani F, Cheraghi L, Noroozzadeh M, Farahmand M, Azizi F. Trends of contraception use among married reproductive age women. Sex Reprod Healthc 2017;12:116-22.

10. Duszczyk M, Fihel A, Kiełkowska M, Kordasiewicz A, Radziwinowiczówna A. Analiza kontekstualna i przyczynowa zmian rodziny i dzietności. Studia i Materiały 2014;2:1-68.

11. Bellieni C. The best age for pregnancy and undue pressures. J Fam Reprod Health 2016;10(3):104-7.

12. Bulley A, Pepper GV. Cross-country relationships between life expectancy, intertemporal choice and age at first birth. Evol Hum Behav 2017;38(5):652-8.

13. Cieślińska B. Bezdzietność jako styl życia. Pogranicze Studia Społeczne 2014;24:277-92.

14. Agrillo Ch, Cristian N. Childfree by choice: a review. J Cult Geogr 2008; 25(3):347-63.
15. Yoldemir T, Oral E. Has fertility declined in recent decades? Curr Opin Obstet Gynecol 2012;24(3):119-26.

16. Wnuk M, Marcinkowski JT. Jakość życia jako pojęcie pluralistyczne o charakterze interdyscy plinarnym. Probl Hig Epidemiol 2012;93(1):21-6.

17. Cahill N, Sonneveldt E, Stover J, Weinberger M, Williamson J, Wei Ch, et al. Modern contraceptive use, unmet need, and demand satisfied among women of reproductive age who are married or in a union in the focus countries of the Family Planning 2020 initiative: a systematic analysis using the Family Planning Estimation Tool. Lancet 2018;391(10123):870-82.

18. Kowalska M, Szemik Sz. Zdrowie i jakość życia a aktywność zawodowa. Med Pr 2016;67(5):663-71.

19. Garncarek E. Zachowania prozdrowotne kobiet młodych, w średnim wieku i starszych. Acta Universitatis Lodziensis. Folia Sociologica 2017;60:201-17.

20. Gruszczyńska M, Bąk-Sosnowska M, Plinta R. Zachowania zdrowotne jako istotny element aktywności życiowej człowieka. Hyg Public Health 2015;50(4):558-65.

21. Xu Z, Yue Y, Bai J, Shen Ch, Yang J, Huang X, et al. Association between oral contraceptives and risk of hemorrhagic stroke: a meta-analysis of observational studies. Arch Gynecol Obstet 2018;1:1-11.

22. Korzeniowska K, Cieślewicz A, Pawlaczyk M, Pawlaczyk M, Jabłecka A. Stosowanie hormonalnej antykoncepcji a palenie tytoniu. Farm Współ 2014;7:101-4.

23. Słopiecka A. Korzystanie przez kobiety z porad lekarza ginekologa. Probl Pielęg 2013;21(1):47-54.

24. Rekomendacje Polskiego Towarzystwa Ginekologicznego dotyczące wskazań i bezpieczeństwa stosowania antykoncepcji hormonalnej oraz wewnątrzmacicznej. Ginekol Pol 2014;85(3):234-9.

25. Paszkiewicz D, Piotrkowski J. Profilaktyka w systemie ochrony zdrowiawalka z nowotworami i chorobami układu krążenia. Kontrola Państwowa 2017;62.4(375):77-96.

26. Leźnicka M, Mierzwa T, Jachimowicz-Wołoszynek D, Żyrkowski J. System indywidualnych zaproszeń a zgłaszalność kobiet na badania profilaktyczne wykonywane w ramach programów z zakresu profilaktyki onkologicznej. Probl Hig Epidemiol 2009;90(2):627-30.

27. Karowicz-Bilińska A. Profil socjalny kobiet a ich udział w Programie Profilaktyki i Wczesnego Wykrywania Raka Szyjki Macicy w Polsce. Ginekol Pol 2009;80:833-8.

28. Kozimala M, Mrozowicz A, Ciechaniewicz W. Program badań profilaktycznych ukierunkowanych na zdrowie kobiet - ocena realizacji w powiecie lubaczowskim. Zdr Publ 2007;117:462-5.

29. Nowicki A, Kosicka B, Lemanowicz M. Satisfaction with life and healthpromoting behaviours in the context of prevention and early detection of breast cancer in physically active women. Oncol Rev 2017;1(7):5-14.

30. Strojek K, Maślanka M, Styczyńska H, Zukow W. Health promoting behaviors and women knowledge about breast cancer prevention. J Educ Health Sport 2017;7(3):166-76.

31. Woźniak M, Brukwicka I, Kopański Z, Kollár R, Kollárová M, Bajger B. Związki stylu życia ze zdrowiem. J Clin Healthc 2015;4:4-9.

32. Kostrzewski Sz, Worach-Kardas H. Wpływ bezrobocia na zdrowie i jakość życia osób w starszej grupie wieku produkcyjnego. Hygeia 2015;50(2):372-82.

33. Woźniak M, Brukwicka I, Kopański Z, Kollár R, Kollárová M, Bajger B. Zdrowie jednostki i zbiorowości. J Clin Healthc 2015;4:1-2.

34. Darmon N, Drewnowski A. Contribution of food prices and diet cost to socioeconomic disparities in diet quality and health: a systematic review and analysis. Nutr Rev 2015;73(10):643-60.

35. Weber D, Nalepa D, Rogala R, Charzyńska-Gula M. Applying of stimulants and social-demographic factors. J Educ Health Sport 2016;6(6):135-45.

36. Nusbaum M, Helton M, Ray N. The changing nature of women's sexual health concerns through the midlife years. Maturitas 2004;49(4):283-91.

37. Bogusz R, Charzyńska-Gula M, Majewska A, Gałęziowska E. Wiedza kobiet $\mathrm{w}$ wieku okołomenopauzalnym na temat profilaktyki raka piersi. Med Og Nauk Zdr 2013;19(4):523-9.

38. Ostrowska A. Profilaktyka zdrowotna: interpretacje, definicje sytuacji, racjonalności (przypadek profilaktyki ginekologicznej kobiet). Stud Socjo 2011;3(202):73-94. 